\title{
Asian Rust Severity in Soybean Sown in December and February in Mato Grosso State
}

\author{
Erlei Melo Reis ${ }^{1}$, Wanderlei Dias Guerra ${ }^{2}$, Laércio Zambolim ${ }^{3}$, Fernando C. Juliatti ${ }^{4}$, José Otávio Menten ${ }^{5}$, \\ Mateus Zanatta ${ }^{1} \&$ Luana Maria de Rossi Belufi ${ }^{6}$ \\ ${ }^{1}$ Instituto Agris, Passo Fundo, RS, Brazil \\ ${ }^{2}$ Associação dos Produtores de Soja e Milho de Mato Grosso, Centro Político Administrativo, Cuiabá, MT, \\ Brazil \\ ${ }^{3}$ Bioagro, Universidade Federal de Viçosa, Viçosa, MG, Brazil \\ ${ }^{4}$ Universidade Federal de Uberlândia, Uberlândia, MG, Brazil \\ ${ }^{5}$ Escola Superior de Agricultura Luiz de Queiróz, Piracicaba, SP, Brazil \\ ${ }^{6}$ Fundação de Pesquisa e Desenvolvimento Tecnológico Rio Verde, Lucas do Rio Verde, MT, Brazil \\ Correspondence: Erlei Melo Reis, Instituto AGRIS, Rua Miguel Vargas, 291 Passo Fundo, RS CEP 99025-380, \\ Brazil. E-mail: erleireis@upf.br
}

Received: August 22, 2021

doi:10.5539/jas.v13n11p127

\author{
Accepted: September 15, 2021 \\ Online Published: October 15, 2021 \\ URL: https://doi.org/10.5539/jas.v13n11p127
}

\begin{abstract}
The objective of this work was to assess the effect of December sowing time with February on the Asian soybean rust severity. In on-farm trials two soybean treatments sowing in December (2020) (DSS.) and February (2021) (FSS) were assessed for Asian soybean rust severity in 24 sites, in three regions of Mato Grosso state. The DSS treatment was established in the growers commercial farms and the FSS in a 5 ha area sown specifically for this treatment. The DSS treatment was conducted in 16 sites and the FSS in eigth. For rust control fungicides with efficacy higher than $60 \%$ were sprayed consisting of DMIs, QoIs and SDHIs in double or triple mixtures, always added by multisites (chlorothalonil, mancozeb, or copper oxychloride). About eighty soybean leaflets from four plots repetitiond, demarcated at random in each field, were taken in each smpling. In laboratory leaflet severity was appraised and area under disease progress curve (AUDPC) calculated. Related to DSS, the AUDPC overall mean was 174 units and receiving 6.9 fungicide spraying and for FSS 26 units with 4.8 fungicide sprayings. Our results reinforce that the sowing time can be changed from the end of December to February to maintain soybean crop sustainability.
\end{abstract}

Keywords: Glycine max, Phakopsora pachyrhizi, site-specific and multisite fungicides

\section{Introduction}

The importance of soybean [Glycine $\max$ (L.) Merr.] in Mato Grosso, the country largest producer state, is reflected in the cultivated area in the last season, reaching 9.6 million hectares (IMEA, 2021).

In Mato Grosso, the main crop disease is Asian soybean rust (ASR) caused by the basidiomycete biotrophic fungus Phakopsora pachyrhizi H. Sydow \& P. Sydow, 1914).

Although with little published scientific data, damage up to $90 \%$ have been cited. Nevertheless, scientifically crop damage can be precisely estimated with the mathematical functions developed by Danelli et al. (2015).

The ASR control has been based on the spray of only three site-specific fungicides (DMI, QoI, SDHI) in double or triple co-formulations, but in mixtures with multisites (chlorothalonil, mancozeb, or copper oxychloride) just in a restricted area.

Despite of available technology the decision-making of first spray has been based on empiricism. The use of site-specific mixtures at risk to the development of resistance is accelerated by their use in the state total grown area, in all sprayings, and an increase in the spraying number, such as in December fields (Reis et al., 2020, 2021a, 2021b). This practice has resulted in the evolution of P.pachyrhizi sensitivity reduction to such 
site-specific fungicides with cross and multiple resistance and with actual efficacy below 40\% (Zambolim, 2019).

The state of Mato Grosso has set a limit on the sowing period for soybeans that may start on September $16^{\text {th }}$, depending on the soil water content, and must be completed on December $31^{\text {th }}$ (INDEA, 2015). Even though, based on practical observations, this resolution has been indicated to reduce the inoculum potential in the state since 2006 and recently arguing that this measure may reduce fungicide directional selection by reducing the spraying number (CAF, 2014).

Soybean fields for the complementary commertial and own growers seed production have been established in December, as a result of IN 002/15. Despite being changed by IN $001 / 21$, nothing has changed in relation to the seeding date and continues to lead to high rust severity as has been recorded, demanding a great number of site-specific fungicide applications in double or triple mixtures (DMI + QoI or DMI + QoI + SDHIs) (Reis et al., $2021 b)$. This practice has reduced the growers profit and with high potencial for environmental damage. On the contrary, the generated technology aims to maximize the growers profit.

As far as 2015, farmers have observed ASR lower intensity, less fungicide applications and better seed quality in February sowing fields. For this reason they have requested, with the Aprosoja-MT support, from the government agencies, authorization to grow soybeans from February 15th with the objective of producing their complementary own seed. This authorization has been denied by state agencies without any scientific evidence for this impediment, but empirically deducing that soybean cultivation in February enters the soybean free-period (from June 15 to September 15) and increases the number of site-specific fungicide applications.

Recently the Ministry of Agriculture issued a rule allowing the seed production even within the soybean free period, which the producers do not agree with, but only in February without entering the soybean free-period.

To solve the impasse between legislators and growers, experiments were carried out during two seasons, showing the greatest rust severity in the DSS and demanding a great number of fungicide applications compared to the FSS (Reis et al., 2020, 2021a) and this situation persists since 2015 without any action by the government plant protection agencies. But, conducting these two experiments was not enough for the state plant sanitary authorities, based on scientific data, to release the FSS.

We hypothesized that, due to the high inoculum pressure, the high rain volume and mainly frequency, and longer plant cycle in the DSS, the rust severity is greater than in the one carried out in February.

The objective of the work was to reconfirm the stated hypothesis that ASR is severer in DSS than in FSS.

\section{Material and Methods.}

\subsection{Experimental Sites}

The on farm trials were conducted in the North, South, and West regions of the state under regional soil and climate differences.

\subsection{Treatments}

The reseach consisted of two treatments: (i) soybean sowing in December (2020); and (ii) sowing in February (2021) with four repetitions.

\subsection{Experimental Plots}

The DSS treatment was established in the growers commercial soybean fields and the FSS in a 5 ha area sown especifically for this treatment. The DSS treatment was established in 16 locations and that of FSS in eight (Table 1). 
Table 1. Experimental areas, sites, and seeding time

\begin{tabular}{lllll}
\hline Farms & Regions & Counties & \multicolumn{2}{c}{ Sowing month/day } \\
\cline { 3 - 4 } (1) Farm 1 & South & Primavera do Leste & $12 / 14 / 2020$ & February \\
(2) Farm 2 & South & Primavera do Leste & $12 / 31 / 2020$ & - \\
(3) Farm 3 A-1 & South & Primavera do Leste & $12 / 29 / 2020$ & - \\
(4) Farm 3 A-2 & South & Primavera do Leste & $12 / 31 / 2020$ & - \\
(5) Farm 4 & South & Primavera do Leste & $12 / 31 / 2020$ & - \\
(6) Farm 5 & South & Campo Verde & $12 / 30 / 2020$ & - \\
(7) Farm 6 A-1 & South & Campo Verde & $12 / 28 / 2020$ & - \\
(8) Farm 6 A-2 & South & Campo Verde & $12 / 28 / 2020$ & - \\
(9) Farm 7 A-1 & North & Cláudia & $12 / 31 / 2020$ & - \\
(10) Farm 7 A-2 & North & Cláudia & $12 / 31 / 2020$ & - \\
(11) Farm 8 A-1 & North & Lucas do Rio Verde & $12 / 29 / 2020$ & - \\
(12) Farm 8 A-2 & North & Lucas do Rio Verde & $12 / 29 / 2020$ & - \\
(13) Farm 9 A-1 & North & Vera & $12 / 31 / 2020$ & - \\
(14) Farm 10 MB01 & West & Campos de Júlio & $12 / 28 / 2020$ & - \\
(15) Farm 10 M3P3 & West & Campos de Júlio & $12 / 28 / 2020$ & - \\
(16) Farm 10 M3P5 & West & Campos de Júlio & $12 / 17 / 2020$ & - \\
(17) Farm 11 & South & Campo Verde & - & $02 / 24 / 2021$ \\
(18) Farm 4 & South & Primavera do Leste & - & $02 / 22 / 2021$ \\
(19) Farm 3 & South & Primavera do Leste & - & $02 / 24 / 2021$ \\
(20) Farm 7 & North & Cláudia & - & $02 / 28 / 2021$ \\
(21) Farm 8 & North & Lucas do Rio Verde & - & $02 / 25 / 2021$ \\
(22) Farm 9 & North & Vera & - & $02 / 22 / 2021$ \\
(23) Farm 12 & North & Marcelândia & - & $02 / 19 / 2021$ \\
(24) Farm 13 & West & Campos de Júlio & - & $02 / 26 / 2021$ \\
\hline
\end{tabular}

In each experimental site, the distance between sampling plots ranged from 100 to $150 \mathrm{~m}$ to avoid interplots interference.

\subsection{Farm Management}

The cultural practices follow the farm management and for the fungicides, mixtures of site-specific (DMI, QoI, SDHI) + multi-site (chlorothalonil, mancozeb or copper oxychloride), with more than $60 \%$ efficacy were recommended. The first spraying was performed when detected rust symptoms/signs and the others considering a 14-16 days protection period as recommended by the fungicide companies. The chemicals within an efficacy list $(>60 \%)$ were freely chosen by the farmers since they were site-specic plus multissite. Fungicides timing and spraying numbers were defined by the growers considering the efficaccy of the last spray and new spray recommended as the rust progressed. In some cases, with Fundação Rio Verde-MT technical assistance, sprayings were recommended at shorter intervals for control reinforcement, mainly due to the rain volume and frequency. Although not scheduled, in some cases tate phytosanitary defense agency made recommendations for fungicde sprayings in the FSS, putting pressure on growers, interfering with the purpose of the research, and increasing unnecessarily the spraying numbers.

\subsection{Rust Assessment}

In each sampling time, central leaflets with the petiole inserted in the main stem of 10 plants per plot were detached (Ogle et al., 1979). The leafletes were taken to the laboratory to appraise the disease severity according to the diagrammatic scale proposed by Godoy et al. (2006). A total of four samplings were perform along the soybean cycle at R2, R4, R5.4, and R6 growth stages.

\subsection{Rainfall Data}

Data were obtained from NIMET (National Institute of Meteorology) weather stations located in Diamanino (West), Poxoréu (South) and Matupá (North) counties.

\subsection{Experimental Design and Statistical Analysis}

The experimental design was composed by two treatments at random with four repetitions and the AUDPC means compared by the Tukey test. 


\section{Results and Discussion}

The work was conducted in 24 fields, 16 sown in DSS and eigth in FSS, located in 12 counties in the South, West and North regions, the main Mato Grosso soybean production areas, covering differences in soils and total and frequency of rainfall.

The evaluations were carried out from January 2021 to May 2021, covering the entire crop cycles.

On average, the rust severity was estimated in 80 leaflets sampling per plot totaling 1920 analysed.

Regarding the number of sprayings, in the DSS treatment, a general mean of six fungicide sprays were performed and in the FSS treatment just four, ane in the western region AUDPC severity ranged from three to four for DSS and five for FSS (Figure 1).

\section{Western Region-December}

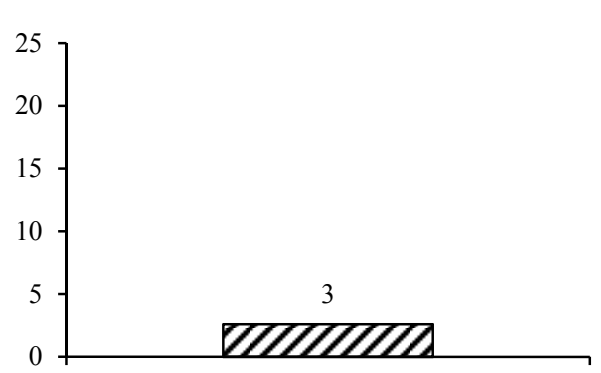

A

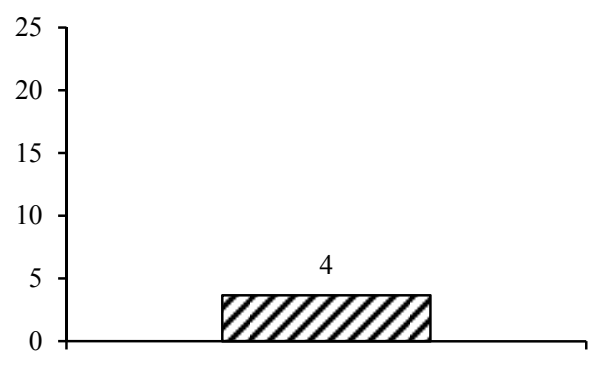

$\mathrm{C}$

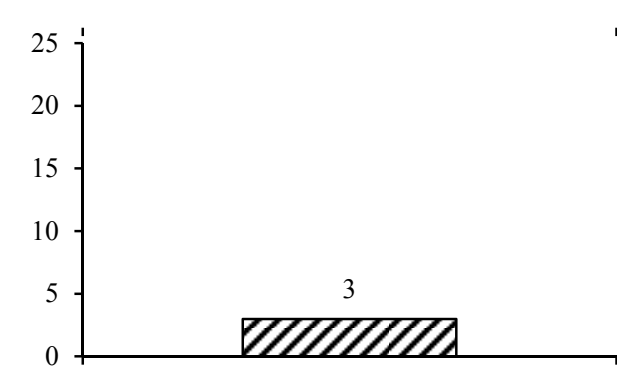

$\mathrm{B}$

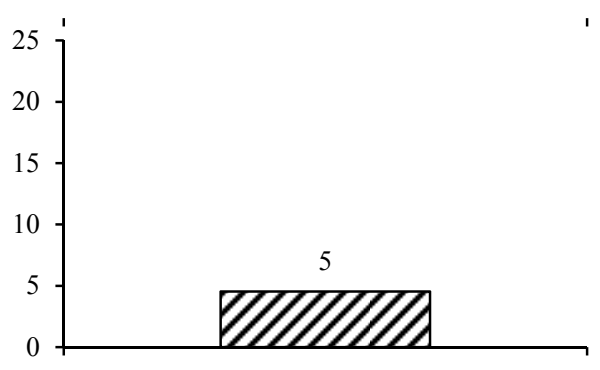

$\mathrm{D}$

Figure 1. Area under the Asian soybean rust progress curves (AUDPC) rated by the leaflet severity in soybean plants sown in December and February in the western region [Campos de Julio, Farm 10 (A); Campos de Julio, Farm 10 (B); Campos de Julio, Farm 10 (C); Campos de Julio, Farm 14 (D)]

In the overall mean there was no difference for rust severity rated by AUDPC for DSS and FSS in the western region (Figure 2). The average number of fungicide applicationspryings were seven in DSS and seven in FSS. This higher and desnecessary sprayings number in FSS was due to the pressure made by the state Plant Sanitary Defense Agency. 


\section{Western Region-February}

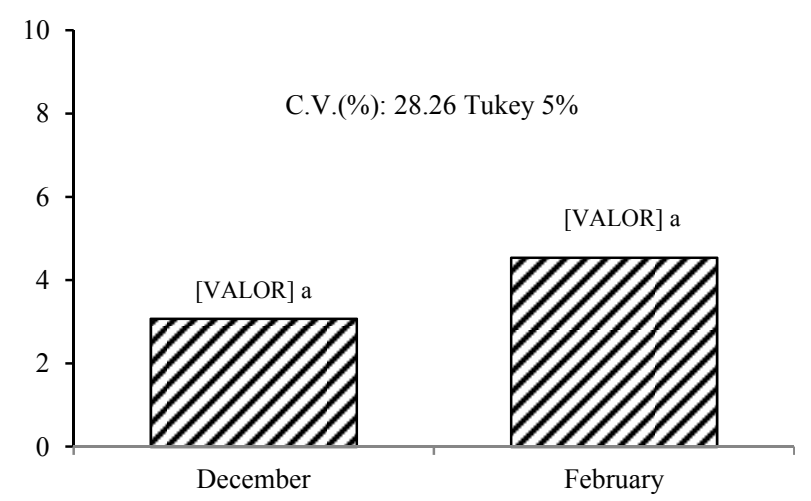

Figure 2. Area under the Asian soybean rust progress curves (AUDPC) rated by the leaflet severity in soybean plants sown in December and February means for the western region. Means in columns followed by the same letter do not differ by Tukey test at 5\%

Considering the southern region, AUDPC ranged from 115 to 1,413 for DSS and from 4 to 118 for for FSS (Figure 3). The mean number of fungicide sprays were 7.6 in DSS and 5.3 in FSS. As in the preceding region there was pression for more sprayings than needed for FSS.

Southern Region-December

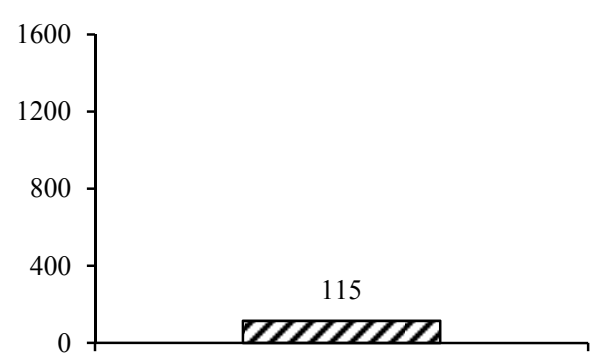

A
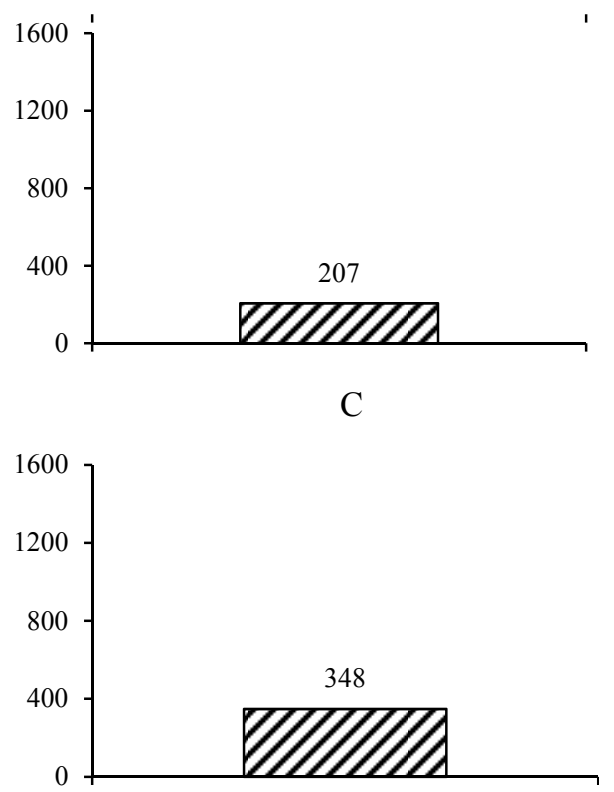

$\mathrm{E}$

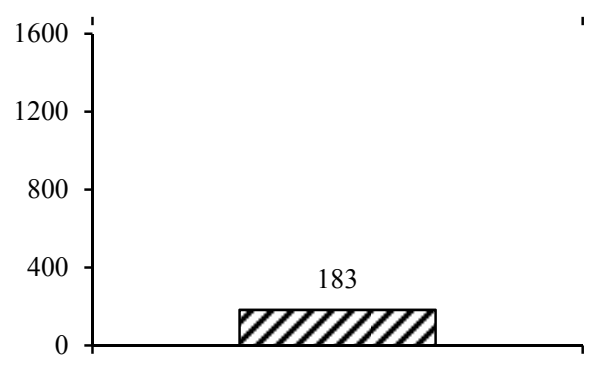

$\mathrm{B}$
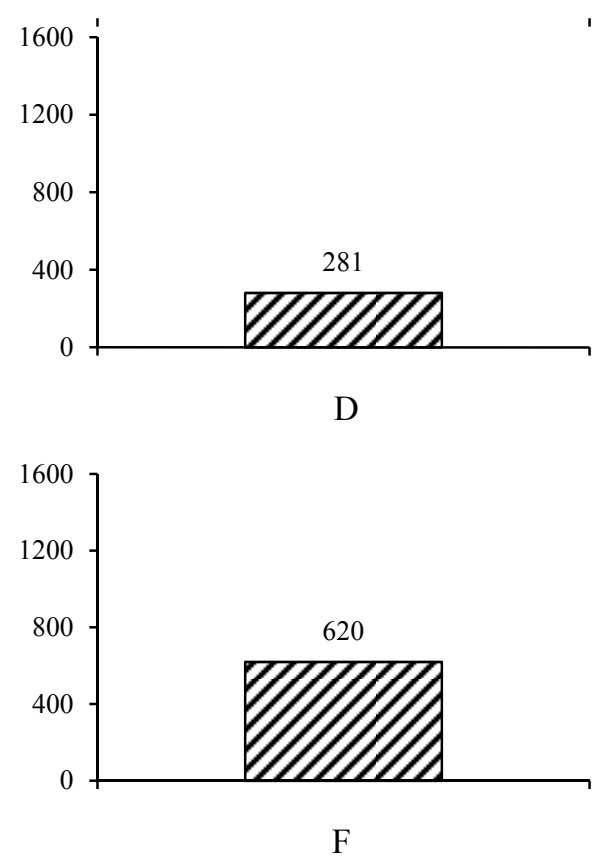

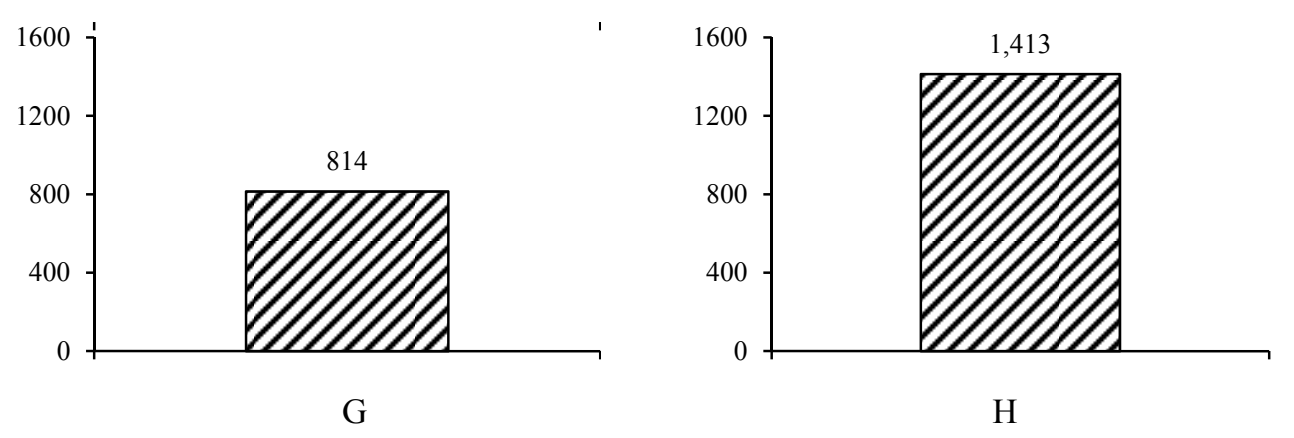

Southern Region-February
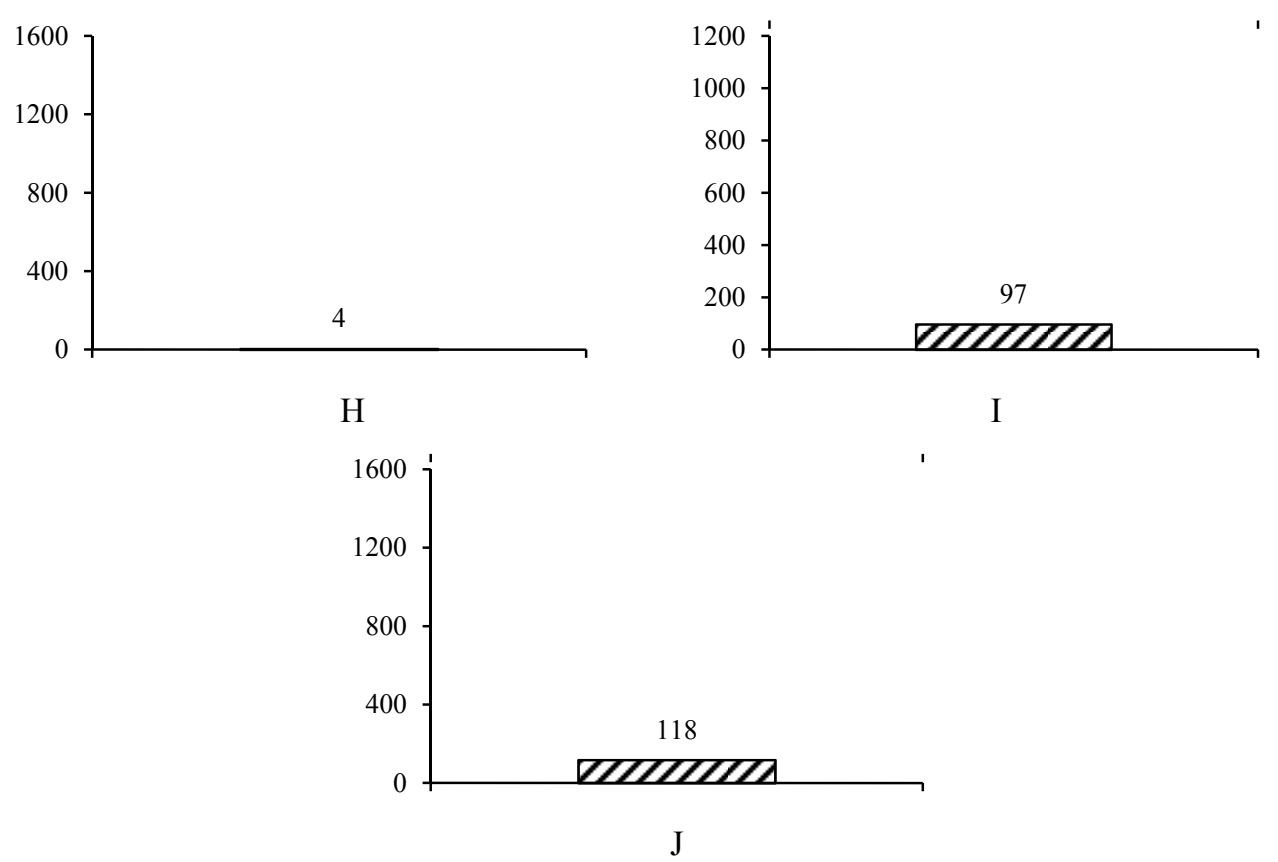

Figura 3. Area under the Asian soybean rust progress curves (AUDPC) rated by the leaflet severity in soybean plants sown in December and February in the southern region [Primavera do Leste, Farm 3 A-1 (A); Primavera do Leste, Farm 1 (B); Primavera do Leste, Farm 2 (C);; Primavera do Leste, Farm 3 A-2 (D); Primavera do Leste, Farm 4 (E); Campo Verde, Farm 5 (F); Campo Verde, Farm 6 A-2 (G); Campo Verde, Farm 6 A-1 (H); Primavera do Leste, Farm 3 (I); Campo Verde, Farm 11 (J); Primavera do Leste, Farm 4 (K).

Analysing the general means rated by the AUDPC for the DSS (498 units) and FSS (73 units), there was a statistical difference between the two treatments (Figure 4). 


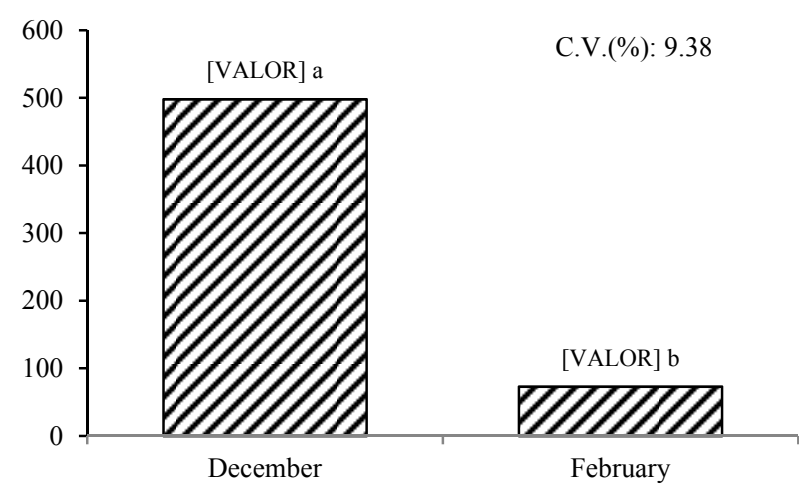

Figure 4. Area under the Asian soybean rust progress curves (AUDPC) rated by the leaflet severity in soybean plants sown in December and February means for the southern regions. Means in columns followed by the same letter do not differ by Tukey test at $5 \%$

The larger AUDPC in DSSs may be due to the following facts: (i) receiving early rust inoculum from neighboring fields that were being harvested, and (ii) the rain in January was slightly above the average (Figure 10) but within the normal range for the region, therefore, it is a typical season according to data from the last 24 years.

North Region-December

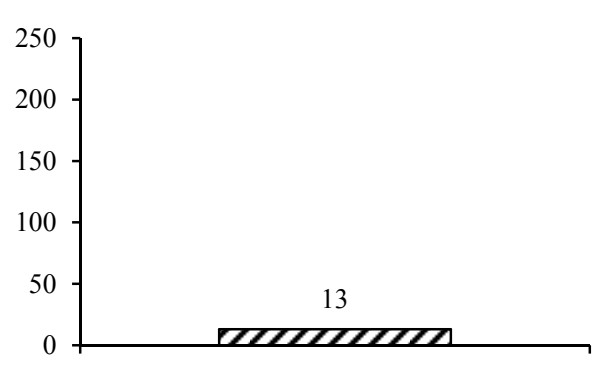

A

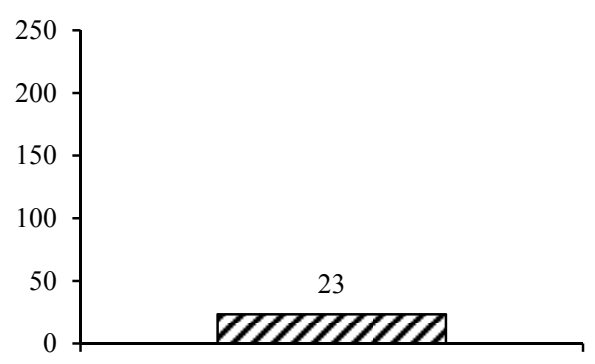

$\mathrm{B}$

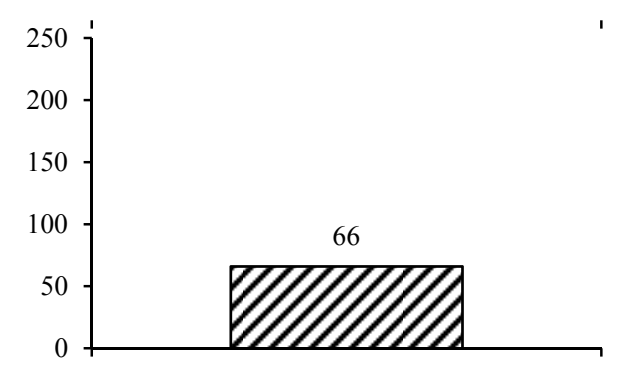

$\mathrm{C}$ 
North Region-February

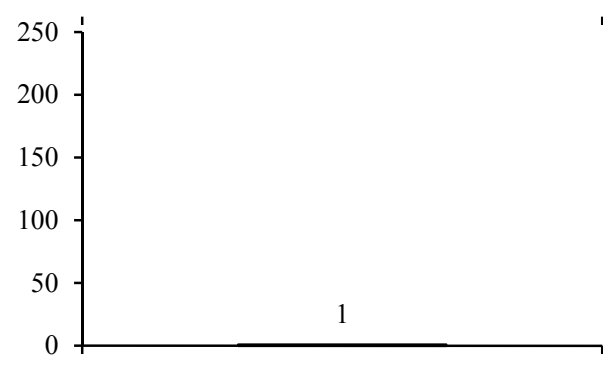

$\mathrm{D}$

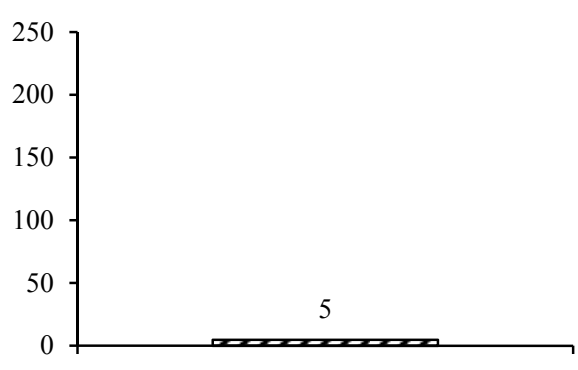

$\mathrm{E}$

Figura 5. Area under the Asian soybean rust progress curves (AUDPC) rated by the leaflet severity in soybean plants sown in December and February in the northern region [Lucas do Rio Verde, Farm 8-A1.1 (A); Lucas do Rio Verde, Farm 8-A1 (B); Vera, Farm 9 (C); Vera, Farm 9 (D); Lucas do Rio Verde, Farm 8 (E)]

Regarding AUDPC general means comparison for the DSS (21 units) and FSS ( 2 units), there was a statistical difference between the two sowing times (Figure 6). DSSs plots received 5.8 fungicide sprays and FSS 3.75.

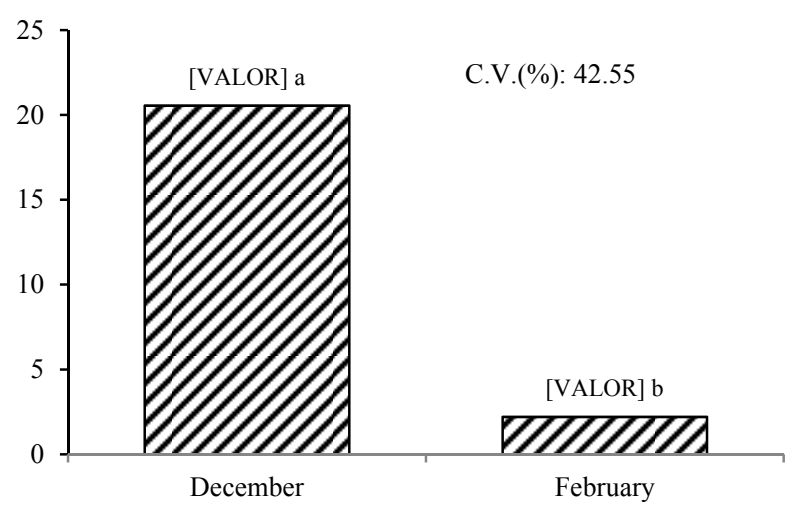

Figure 6. Area under disease progress curve (AUDPC) rated by the leaflet severity in soybean plants sown in December and February means for the northern region. Means in columns followed by the same letter do not differ by Tukey test at $5 \%$

For the overall means there were statistical difference between treatments (DSS and FSS), on rust severity rated by the AUDPC. For DSS the area was 174 and for FSS 26 units (Figure 7). In the overall means DSS were saprayed 6.9 times while in FSS 4.8. 


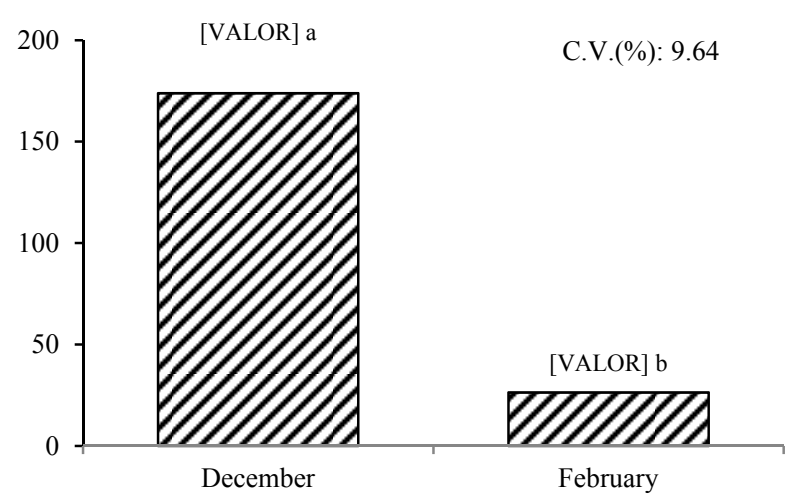

Figure 7. Overall means of the area under disease progress curve (AUDPC) rated by the leaflet severity in soybean plants sown in December and February in the northern, western, and southern regions. Means in columns followed by the same letter do not differ by Tukey test at $5 \%$

It has been noticed in MT since 2015 growing season when was issued the State Normative Instruction 002/2015, that DSS showed greater severity than FSS and, therefore, receiving a great number of fungicide sprayings, as scientifically documented in previous reports (Reis et al., 2020, 2021) as well in the present work (Figure 7).

The difference in the rust severity between the two sowing times can be attributed to climate effect, such as rain volume (Del Ponte et al., 2006) but mainly to its frequency during the two crops (Melching et al., 1989). The mounthly average comparison of current rainfall showed great volume and frequency (Figures 8, 9 and 10) during the DSS compared to FSS which reinforces our hypothesis.

Both total rainfall and the number of rainy days for every region were computed according to the sowing date of each treatment.

\subsection{Western Region}

In this region there were three DSS areas and one in FSS. Similar to the other regions, this season was atypical, with lower historical rain volumes at the season begginning (Figure 8), in October and November, which resulted in sowing delay and on the rust onset in the region. Rust was first detected in the western region on February $9^{\text {th }}$, 2021 (Campo Novo do Parecis) and on February 17 ${ }^{\text {th }}, 2021$ (Tangará da Serra), 30 and 15 days after rust occurrance in the last season.

On the other hand, as in other regions, there was an increase in the rain volume and frequency in March and April. The highest rainfall in February made difficult to control the rust in the areas DSS which, with 25 rainy days out of the 28 in the month, volume $(431.8 \mathrm{~mm})$. The high rainfall was also maintained during March increasing the rust pressure in FSS with greater need for sprayings, and both seeding times receiving six spraying. Despite the high rust inoculum coming from DSS, the highest number of sprayings in April and May, was due to pressure for applications by the state phytosanitary defense agency. There was a case where the application was repeated two days later, unnecessarily increasing the number of sprays that were extended until May. During a visit to the experimental area carried out by the researchers, it was observed that unnecessary applications that had been made and still programmed scheduled for the month of May at the FSS. This same situation occurred in the FSS areas of the southern region, which were informed to the researchers who did not authorize extra applications, but even so they wew pressured by the state plant sanitary defense agency, made extra sprayings, which increased the number in February, influencing the survey results. 


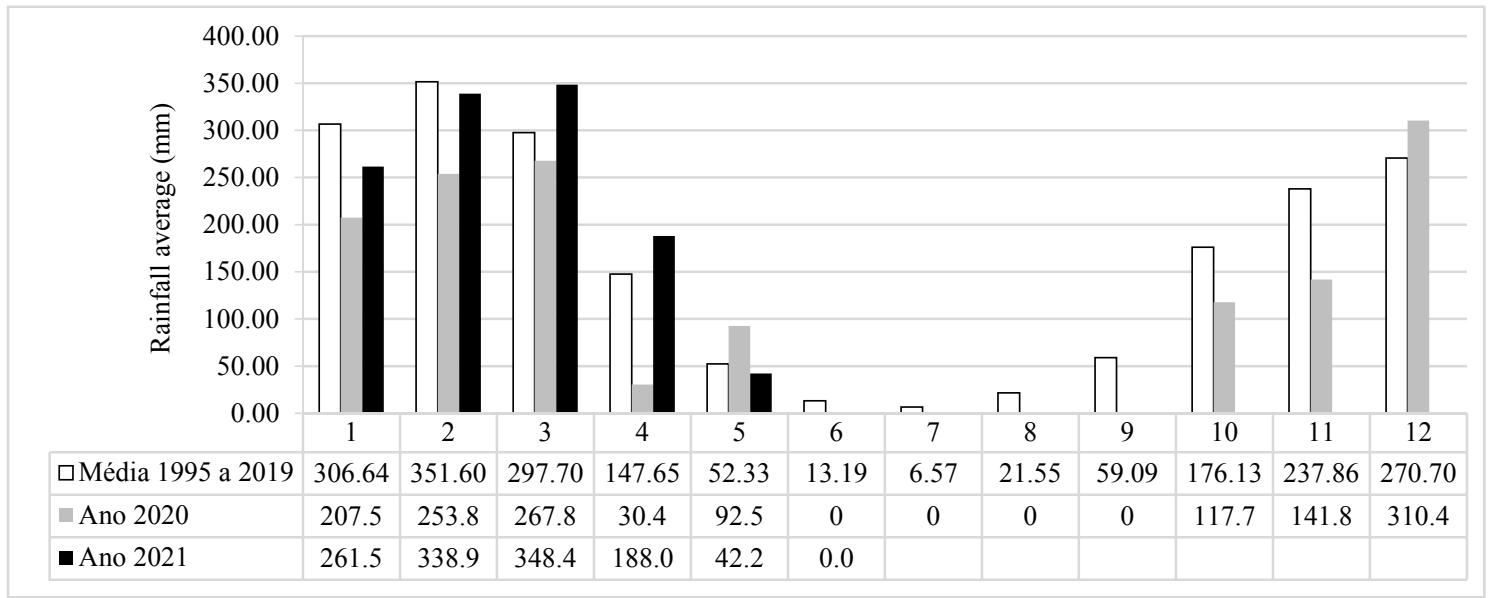

Figure 8. Mean rainfall (mm) from January to May 2021, compared to 2020 and to 1995-2019 average at Diamantino, MT. Source INMET (2021). The white bars represent the mounthly hstorical average, from 1995 to 2019, greys to 2020 and black the rainfall occurred in 2021, between the months January to May.

\subsection{Northern Region}

Historically, rust has been less intense in this region due to low altitudes and high temperatures. The lower rust pressure has already been shown in the two comparative works previously published (Reis et al., 2020, 2021a).

In this season, just as in the south and west regions, this was the situation throughout Mato Grosso, with a lower rain volume than the historical average for the last 25 years. The rain deficit in October and November (Figure 9), only was recovered from February, remaining above average in the next months until April. Even with these rain volumes in April and May, the rust severity in the FSS was statistically lower than in the DSS, as the frequency was lower (Figure 6).

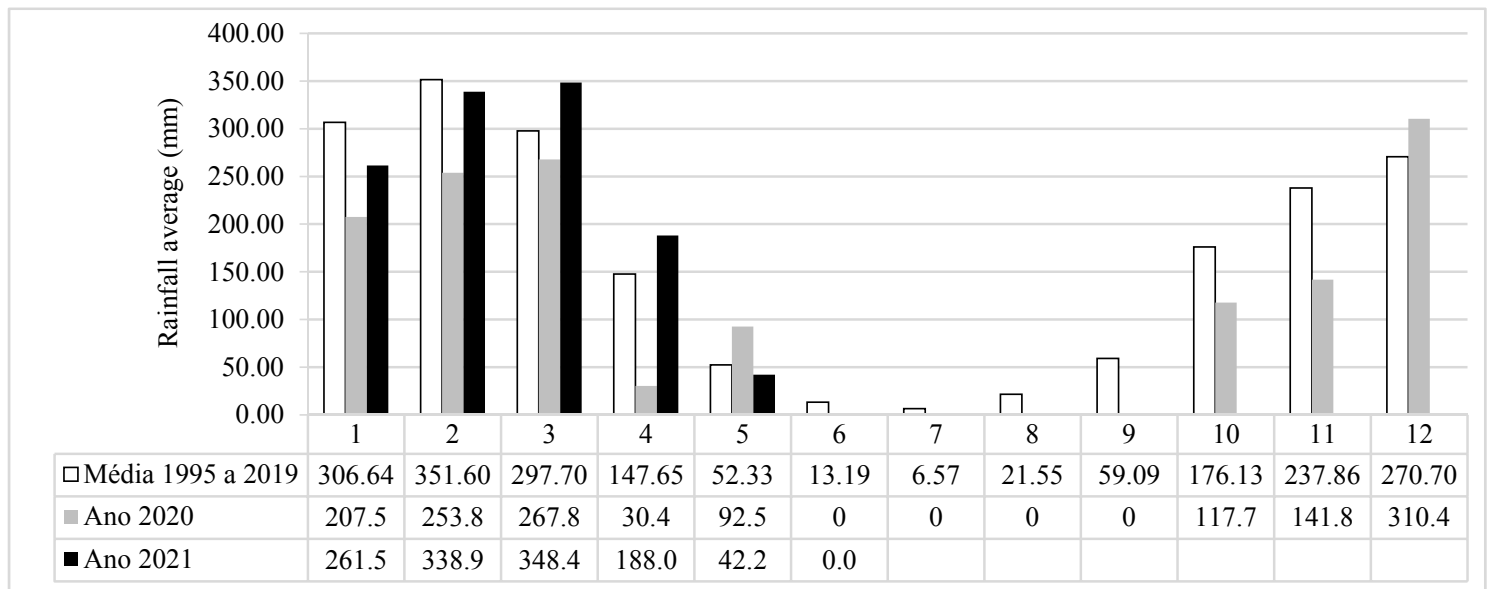

Figure 9. Mean rainfall (mm) from January to May 2021, compared to 2020 and to 1995-2019 average at Matupa, MT. Source INMET (2021). The white bars represent the monthly hystorical average, from 1995 to 2019 and grey to 2020 and black the rainfall occurred in 2021, between the months January to May.

\subsection{Southern Region}

The rain event in the southern region, considering the total rainfall occurring during the DSS cycle was 719.0 $\mathrm{mm}$ and the 40 rainy days. On the other hand, for the FSS cycle rainfall was $579 \mathrm{~mm}$ and 31 rainy days (Figure 10). Total rainfall and mainly its frequency may explain the difference in the AUDPC between the two treatments (Figure 3). 


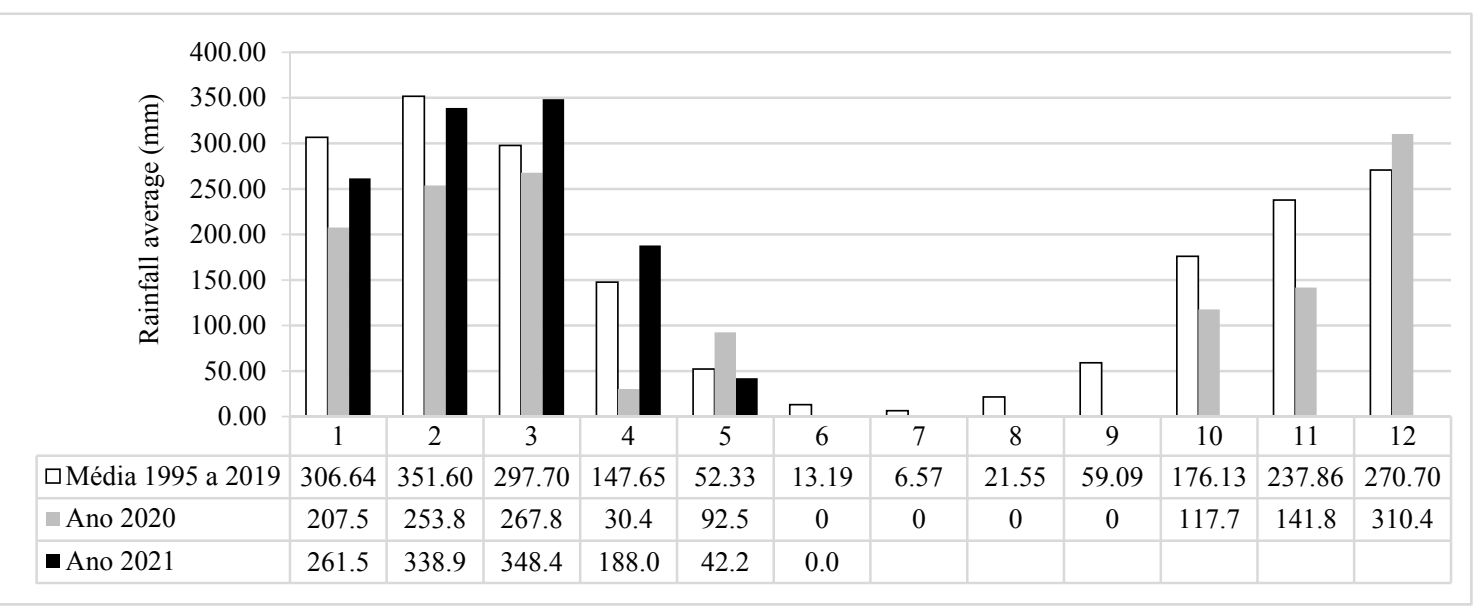

Figure 10. Mean rainfall (mm) per ten days period from January to May 2021, compared to 2020 and to 1995-2019 average at Poxoréu, MT. Source INMET (2021). The white bars represent the mounthly decennial historical average, from 1995 to 2019 and grey to 2020 and black the rainfall in 2021, between the months January to May.

In this season, rust was detected in Primavera do Leste on December $30^{\text {th }}, 2020$ and the second detection on January $15^{\text {th }}, 2021$. Although in this season the rust was detected at the same time as in the previous season, January $1^{\text {th }}, 2020$, the high rain volumes and frequencies from the end of January to March were higher than the averages of the last 25 years registered in Poxoréu (Figure 10). It is likely that this high rainfall increased rust severity, especially in March for DSS. On the other hand, the FSS, although influenced by interplot interference, due to the proximity of the DSS treatment, even with this high inoculum in March, after harvesting the DSS areas and reduced rain volume and frequency in April and May (Figure 10), a better rust control efficacy was achieved.

These earlier rust detections in the region, in commercial crops, which are normally close to their end cycle, means that, at the harvesting, in early January, there is a great spore dispersion to neighboring crops and from there to the DSS, which justifies the high pressure in these later plantings.

Although $50 \%$ of the sprayings were performed in DSS, they were not enough for efficient disease control as shown by severity data. Sprayings were also with the shortest interval of seven days. We should emphasize that the FSS crop was located at $1,500 \mathrm{~m}$ far from the DSS and probably due to the spores migration the first two sprayings were at the shortest interval. Similar condition occurred for DSS, on April $13^{\text {th }}$, requiring three sprayings per week after harvesting DSS.

In the Primavera do Leste, southern region, similar fact happened in one experimental site, indicative of the interplot interference. It is likely that this situation led to an almost uncontrolled rust in DSS, where farm advisers recommended applying weekly or even with shorter intervals when rain occurred soon after the last application. Soybean crop in this month received six out of nine site-specific sprayings, even with multi-site fungicides.

This was the reason for a greater need for fungicide spraying in FSS made in this season in the southern region, a situation that would not have occurred in the absence of DSS, which have only been done because of the non-authorization of planting in February. This was also the trend in FSS in Primavera do Leste, due to interplot interference. To elucidate the importance of the interference among plots and sowing time, we exemplify with the Entre Rios farm case, which received a corn border to separate the FSS plots sown in the February last week. Despite the high rainfall and the disease having been detected a week later than at Canario farm, only two sprays in March and three in April were performed. This site was the one that resulted in the lowest rust severity of all areas in the southern region, indicating that the farther the plot and its isolation from inoculum sources, the better the efficacy of ASR control (Figure 3). This is the situation nearest to the reality of what FSS will be, as long as there are no soybean cultivation in December

In southern region, an increase in the number of sprayings in FSS compared to previous season experiments may be due two reasons, but even so the mean number of sprayings in FSS was lower than in DSS: (i) delay in the official authorization for the FSS, many farmers did not reserve the best areas, therefore, when authorized, they had to choose areas that were close to DSS; (ii) the non-authorization of growing larger areas in FSS, where experimental units were be installed, made the producers sowed most of their crops at the end of Decembrt; (iii) 
the high DSS inoculum pressure when near the FSS, increasing interplot interference. In one site the farmer had to destroyed part of the DSS to open a small area for the February experiment, which was literally surrounded by the DSS and resulting in the greatest rust pressure. Even in sites where the DSS and FSS were more distant, there was still a strong influence from the DSS inoculum on the FSS.

Soybean predisposition to rust infectons can also be attributed to great leaf area index with a closer canopy in DSS maintaining a longer duration of leaf wetness fulfilling the water requirement for infection of 6-7 $\mathrm{h}$ of continuous daily leaf wetness (Melching et al., 1989) and less predisposition in FSS.

Other important point is that the FSS is less subject to the inoculum amount from the surrounding soybean farms than DSS, when the majority have been harvested, and associated with the lower rain volume and mainly frequency as discussed.

Although, rainfall occurring in the DSS cycle was the highest and the lowest in FSS the rust severity should not be related to the rain volume, but rather to its frequency. However, Del Ponte et al. (2006.) have shown relation between rust final severity with total rainfall. But we may question their findings suggesting that the major effect was due to rain frequency.

Limiting the sowing time, as actually recommended, is not the most efficient strategy to make chemical control of soybean rust with more efficacy. The normative Instruction 001/21-INDEA (2021) deals with the regulation of soybean sowing date in order to reduce the number of fungicide sprayings, and so, to reduce the directional selection. But, to achieve this goal, as statiscally shown by our data, do not grow soybeans in DSS but rather in FSS.

The ASR showed the greatest severity in FSS in 2021 season compared to those occurring in the prevoius seasons. This can be explained by the extemporaneous rains that occurred in March, 2021 (Figures 8, 9 and 10) which increased the rust pressure on the DSS and, consequently, greater inoculum pressure for the FSS. Our hypothesis, was comfirmed due to the lowest rain in April and May, even with high inoculum pressure in DSS a situation that would not exist if FSS were authorized, still the efficiency of fungicides showed the feasibility of replacing DSS plantations for FSS.

It is important to discuss that an efficient strategy to fight directional selection has been the reduction of site-specific fungicide applications (Ishii \& Hollomon, 2015). To fulfill this objective in Mato Grosso, has been imposed by legislation limiting the soybean sowing time. However, more importante than sowing time limitation is the highest frequency of sprayings reaching P. pachyrhizi, performed for several seasons and in a large area, on soybean weeds amid cotton crop where, so far, nothing has been done to be mitigated (Zambolim, 2019; Reis et al., 2021b). A second strategy is the application of co-formulation allways containing site-specific + multissite fungicides as performed in our work (Ishii \& Hollomon, 2015).

In summary: DSS: (a) Soybeans receiving maximum inoculum amount from the lagest soybean cultivated surrounding areas; (b) Higher rain volume and frequency during the soybean cycle (Figure 2 and 3); (c) Longer soybean cycle; (d) Demanding larger number of fungicide sprayings; and (e) Decison making for the first spraying empirically taken. February grown soybean: (a) Lower inoculum potential considering that the most surrounding soybean areas have been harvested; (b) Lower rain volume and mainly frequency during the soybean cycle; (c) Fewer number of fungicide application; (d) Use of multiseites in all sprayings; (e) Shorter plant height and lower leaf area index, facilitating the plants coverage by fungicides; (f) Shorter soybean cycle; (g) Decision making to time the first spraying based on the economic damage threshold (EDT) (Danelli et al., 2015).

The results of our research confirm statistically that the sowing period can be changed from the end of December to February, but always with the use of multisites fungicides with the highest efficacy. This change, in accordance with the basic principle of disease control, escape, implies a significant reduction in risks, less environmental damage and a reduction in economic costs and is still in accordance with the principles of IN 002/2015, updated by IN 001/2021.

In relation to P. pachyrhizi survival in the state, another point must be discussed: when FSS treatment was in the field there were no other cultivated farms with soybeans and, at the time of its harvest, there were no more volunteer plants where the spores can be deposited. Even if there were voluntary plants, they should not be infected due to lack of leaf wetness required for the infection (Melching et al., 1989) and f P. pachyrhizi survivalo in the off-season. It is reinforced that FSS, unlike those of DSS, ensure a greater economic sustainability of the crop both for the farmer who make their own seed and for the others who did not suffer the inoculum pressure of these late sowings. 
The seed quality, mainly vigor, is one of the main factor for agriculture success. Therefore, the best seed quality obtained in FSS also would require a shorter storage period resulting in still better quality. Seed producers in Mato Grosso state are encouraged to use the technology generated in our work to produce quality seeds, especially producing and storing them in refrigerated warehouses in regions far from the current producing region, for example along the BR 163 axis, where there is no tradition for seed production.

Regarding soybean crop sustainability, we should consider the economic and environmental aspects. In the DSS, compared to FSS, due to the reduction in the fungicides applications, the exchange of sowing times represents economic and environmental advantages for producers who conducted the experiment in their fields. They will have better seed quality, due to reduced rainfall at harvest and shorter storage period, which will already represent gains in productivity, in addition to the fact that they have at their disposal the materials they need at the seeding time. This possibility of seeding in other times can also be extended to commercial seed producers, as they have also seeding in December to complement seed amount that were not able to produce during the normal season. They are certainly looking for seed amount and quality, which will also result in better crops for their customers and a reduction in the number of complaints. It is feasible that, wheather the supervised seed producers use FSS as the better sowing time with better seed quality and reduced storage costs, the other farmers may reduce their need to produce their own seed considering the improving seed quality.

In relation to quality, data from samplings carried out by Aprosoja-MT, among its members, show that in recent seasons there has been a significant reduction in germination and vigor of commercialized seeds among soybean producers in MT.

Taking into account, the site-specific fungicides efficacy reduction, by having a smaller spraying number, and allways combined with associated multissites, this will result in less selection pressure on the fungus populations, which will also represent lower demand for fungicides in the following crops. Less selection pressure results in less chemical usage or maintenance of current levels thus reducing costs to producers and less chemical pressure on the environment and increasing farmers profitability through lower production cost and better control of ASR throughout the state and even in the country.

In relation to the efficacy reduction of site-specific fungicides, by having a smaller number of applications, and allied to the multissites use, this will result in less selection pressure on the fungal populations, which can represent lower use of fungicides for the following crops. Less selection pressure results in less chemical usage or maintenance of current levels thus increasing profit through lower production cost and better ASR control. It is regrettable that public research institutions, as well as the sanitary defense agencies, are not aware of this situation and, together with the research, seek an alternative to final season seeding.

Another question that deserves discussion, since the subject seems to have taken more political than scientific course is the discussion of royalty payment for the used technology when multiplied and used as seeds by the farmers. Both the growers and Aprosoja - MT agree with royalties payment for the used germoplasm.

Finally, no information was found in the consulted scientific literature to support the DSS considering the principles of integrated disease management. On the contrary, once again based in scientific method has been shown the advantages of soybean cultivation in February in Mato Grosso state.

\section{Acknowledgements}

Authors are indebted to Aprosoja for the financial support of this research.

\section{Referencies}

CAF (Consórcio Antiferrugem). (2014). Moção CAF futuro do controle de doenças da soja no Brasil 2013/14. Retrieved from http://www.consorcioantiferrugem.net/\#/conteudos/view/1

Danelli, A. L. D., Reis, E. M., \& Boaretto, C. (2015). Critical-point model to estimate yield loss caused by Asian soybean rust. Summa Phytopathologica, 41(4), 262-269. https://doi.org/10.1590/0100-5405/2003

Del Ponte, E. M., Godoy, C. V., Canteri, M. G., Reis, E. M., \& Yang, X. B. (2006). Models and applications for risk assessment and prediction of Asian soybean rust epidemics. Fitopatologia Brasileira, 31, 533-544. https://doi.org/10.1590/S0100-41582006000600001

Godoy, C. V., Koga, L. J., \& Canteri, M. G. (2006). Diagrammatic scale for assessment of soybean rust severity. Fitopatologia Brasileira, 31, 63-68. https://doi.org/10.1590/S0100-41582006000100011

IMEA (Instituto Mato-grossense de Economia Agropecuária). (2020a). Indicador Soja. Retrieved from http://www.imea.com.br/imea-site/indicador-soja 
INDEA (Instituto Mato-Grossense de Defesa da Agropecuária). (2015). Intrução Normativa Conjunta SEDEC/INDEA No. 002/2015. Retrieved from http://www.indea.mt.gov.br

Ishii, H., \& Hollomon, D. W. (2015). Fungi resistance in plant pathogens. Principles and guide to practical management (p. 490). Springer Japan. https://doi.org/10.1007/978-4-431-55642-8

Melching, J. S., Dowler, W. M., Koogle, D. L., \& Royer, M. H. (1989). Effects of duration, frequency, and temperature of leaf wetness periods on soybean rust. Plant Disease, 73(2), 17-122. https://doi.org/10.1094/ PD-73-0117

IMEA (Instituto Mato-grossense de Economia Agropecuária). (2020a). Indicador Soja. Retrieved from http://www.imea.com.br/imea-site/indicador-soja

Ogle, H. J., Byth, D. E., \& McLean, R. J. (1979). Effect of rust (Phakopsora pachyrhizi) on soybean yield and quality in South-eastern Queensland. Australian Journal of Agricultural Research, 30, 883-893. https://doi.org/10.1071/AR9790883

Reis, E. M., Pasquali, R. M., Belufi, L. M. R., \& Guerra, W. D. (2020). Comparative severity analysis of Asian soybean rust in soybean farms sown in December and February in Mato Grosso, 2018/19 growing season. Journal of Agricultural Science, 12(9), 130-137. https://doi.org/10.5539/jas.v12n9p130

Reis, E. M., Belufi, L. M., Rossi, Guerra, W. D., Zambolim, L., \& Zanatta, M. (2021a). Asian soybean rust severity sowed in different seasons. Journal of Agricultural Science, 12(10), 240-251. https://doi.org/ 10.5539/jas.v12n10p240

Reis, E. M., Zambolim, L., \& Dias Guerra, W. (2021b). Directional selection of Phakopsora pachyrhizi towards site-specific fungicides in Mato Grosso state. Journal of Agricultural Science, 13(6), 100-109. https://doi.org/10.5539/jas.v13n6p100

Sydow, H., \& Sydow, P. (1914). A contribution to knowledge of parasitic fungi of the island of Formosa. Annales Mycologici, 12, 108.

Zambolim, L. (2019). Vulnerabilidade no controle químico da ferrugem da soja com o emprego de fungicidas sistêmicos de mecanismo de ação específico. In L. Zambolim (Eds.), O que engenheiros agrônomos devem saber para orientar corretamente o uso de produtos fitossanitários (pp. 326-371). Universidade Federal de Viçosa, Viçosa, Minas Gerais.

\section{Copyrights}

Copyright for this article is retained by the author(s), with first publication rights granted to the journal.

This is an open-access article distributed under the terms and conditions of the Creative Commons Attribution license (http://creativecommons.org/licenses/by/4.0/). 